\title{
JUBILEUSZ PROFESORA JERZEGO MALCA
}

5 grudnia 2012 r. w Sali senackiej Krakowskiej Akademii im. A.F. Modrzewskiego odbył się jubileusz 40-lecia pracy naukowej wybitnego historyka prawa Profesora Jerzego Malca, rektora Akademii Krakowskiej, połączony z wręczeniem przygotowanej z tej okazji księgi jubileuszowej. Uroczystość w imieniu władz Krakowskiej Akademii otworzył kanclerz uczelni dr Klemens Budzowski, który przywitał przybyłych znakomitych gości, a w szczególności przedstawicieli władz Uniwersytetu Jagiellońskiego w osobach Jego Magnificencji Rektora UJ prof. dr hab. Wojciecha Nowaka, Prorektora UJ prof. dr hab. Andrzeja Mani oraz Prodziekana Wydziału Prawa i Administracji UJ prof. dr hab. Janiny Błachut. Kariera naukowa Jubilata w ogromnej mierze bowiem związana była z krakowską Alma Mater, w której zdobył najważniejsze stopnie i tytuły naukowe oraz przez wiele lat kierował Katedrą Historii Administracji i Myśli Administracyjnej UJ.

Uroczystość zaszczycili także swoją obecnością przedstawiciele zagranicznych ośrodków, z którymi Akademia Krakowska utrzymuje bliską współpracę, głównie z Ukrainy, m.in. Rektor Ekonomiczno-Prawnego Uniwersytetu w Kijowie prof. Taras Finikov. Licznie też przybyli na uroczystość historycy prawa, reprezentujący środowiska naukowe Uniwersytetu Gdańskiego, Uniwersytetu Śląskiego, Uniwersytetu im. Mikołaja Kopernika w Toruniu, Uniwersytetu Wrocławskiego i Uniwersytetu im. Marii Curie-Skłodowskiej w Lublinie. W uroczystości udział wzięło liczne grono przyjaciół, kolegów i współpracowników Jubilata zarówno z Uniwersytetu Jagiellońskiego, jak i Krakowskiej Akademii.

Jubileuszowe spotkanie prowadziła Prorektor Akademii Krakowskiej, prof. dr hab. Barbara Stoczewska, która odczytała nadesłane listy gratulacyjne, jakie skierowali do Jubilata m.in. prof. dr hab. Barbara Kudrycka, Minister Nauki i Szkolnictwa Wyższego, Jego Eminencja Stanisław Kardynał Dziwisz, Metropolita Krakowski, prof. dr hab. Karol Musioł, Przewodniczący Rektorów Szkół Wyższych Krakowa i prof. dr hab. Jerzy Woźnicki, Prezes Zarządu Fundacji Rektorów Polskich. Następnie w imieniu Rady Wydziału Prawa i Administracji UJ podziękowania za wkład wniesiony w życie naukowe Uniwersytetu Jagiellońskiego i życzenia dalszych sukcesów złożyła Jubilatowi profesor Janina Błachut. Z kolei w imieniu całej społeczności uniwersyteckiej gratulacje i życzeniami przekazał J.M. Rektor Uniwersytetu Jagiellońskiego, profesor Wojciech Nowak. Slowa wielkiego uznania dla naukowej i organizacyjnej działalności Jubilata wyrazili także przedstawiciele kilku szkół wyższych, działających w miastach za wschodnią granicą (Kijów, Gorlivka, Baranowicze).

Podczas uroczystości laudację wygłosił prof. dr hab. Wojciech Witkowski, który w znakomitym krasomówczym stylu przedstawił drogę naukową i osiągnięcia organizacyjne Jubilata. Przypomniał, że Jerzy Malec jeszcze jako student ogłosił swoją pierwszą publikację naukową pt. 120 lat działalności Towarzystwa Biblioteki Shuchaczów Prawa Uniwersytetu Jagiellońskiego (nakładem Uniwersytetu Jagiellońskiego, Kraków 1971). W 1978 r. obronił na Wydziale Prawa i Administracji UJ rozprawę doktorską pt. Zaręczenie Wzajemne Obojga Narodów. Z dziejów stosunku Polski do Litwy w II polowie XVIII wieku (1764-1792), napisaną pod kierunkiem prof. dr hab. Stanisława Grodziskiego w Zakładzie Historii Państwa i Prawa Polskiego. Laudator 
pokazał najważniejsze obszary naukowych zainteresowań Jubilata, które obejmują w przeważającej części historię federalizmu oraz historię administracji w czasach nowożytnych, a nadto studia nad dziejami nauki i nauczania prawa w XVIII-XX w.

$\mathrm{Za}$ godne podkreślenia w dorobku naukowym Profesora Jerzego Malca uznano w laudacji dzieje federalizmu polsko-litewskiego w XVIII w., które stanowiły przedmiot Jego dysertacji doktorskiej. Podkreślono, że Jerzy Malec pierwszy w nauce historycznoprawnej przeprowadził rewizję poglądu, według którego od uchwalenia ustawy zasadniczej z 1791 r. Rzeczpospolita stała się państwem jednolitym. Jego ustalenia w tym względzie przyjęły się w nauce i wprowadzone zostały do najnowszych syntez dziejów państwa i prawa polskiego. Profesor Wojciech Witkowski jako drugą dziedzinę, stanowiącą domenę zainteresowań naukowych Jerzego Malca, wskazał dzieje administracji i myśli administracyjnej. Podniósł, że Jubilat jest jednym z niewielu badaczy, którzy najwcześniej zajęli się tą dziedziną nauki, przyczyniając się do jej rozwoju w następnych latach.

Problematyce polskiej myśli administracyjnej poświęcił J. Malec rozprawę habilitacyjną pt. Polska myśl administracyjna XVIII wieku, Kraków 1986, którą, jak stwierdzono, cechowało głównie podejście porównawcze, prezentujące naukę o policji w Polsce w powiązaniu z doktrynami i literaturą zachodnioeuropejską. Szczególne miejsce $w$ dorobku naukowym Jubilata zajęły $w$ ocenie laudatora prace naukowe nad historią administracji, a zwłaszcza napisane wspólnie z żoną Dorotą Malec podręczniki o zasięgu ogólnopolskim: Historia administracji nowożytnej, Kraków 1996 oraz Historia administracji i myśli administracyjnej, Kraków 2000, które służą za podstawę dydaktyki w kilkudziesięciu uczelniach, zarówno publicznych jak i niepublicznych.

W laudacji profesora Wojciecha Witkowskiego nie zabrakło także słów uznania dla dorobku Jubilata na polu organizacji nauki i szkolnictwa wyższego w Polsce. Znaczną bowiem część swej aktywności zawodowej poświęcił Profesor Jerzy Malec zagadnieniu reformy szkolnictwa wyższego w Polsce w ramach działalności Konferencji Rektorów Zawodowych Szkół Polskich, którą kierował w latach 2005-2008. Jako przewodniczący KRZaSP przeprowadził $\mathrm{m}$. in. akcję przygotowywania statutów wzorcowych dla wyższych szkół zawodowych publicznych i niepublicznych, związaną $\mathrm{z}$ wymaganiami wprowadzonymi przez nową ustawę o szkolnictwie wyższym. $\mathrm{Z}$ jego inicjatywy został przygotowany całościowy projekt nowelizacji ustawy, zawierający propozycje zmian w kwestiach najbardziej poruszających środowisko uczelni zawodowych. Jubilat przyczynił się wreszcie do przyjęcia Konferencji w poczet członków European Association of Institutions of Higher Education, włączając ją tym samym w europejskie struktury i zapewniając silną reprezentację polskim uczelniom $w$ ramach tej organizacji.

Kulminacyjnym punktem uroczystości było wręczenie Profesorowi Jerzemu Malcowi księgi jubileuszowej przez jej redaktorów (prof. dr hab. Stanisława Grodziskiego i autora niniejszego sprawozdania), w której znalazły się prace 65 historyków prawa, historyków idei i prawników, nie tylko polskich, ale także z Niemiec i Anglii. Dwutomowej księdze patronuje triada: regnare, gubernare, administrare, stanowiąca w przekonaniu redaktorów dobre motto nie tylko dla merytorycznej zawartości księgi, ale także dla naukowych zainteresowań Jubilata, jak i jego organizacyjnych dokonań. 
Tom pierwszy księgi o tytule Prawo $i$ władza na przestrzeni wieków zawiera zatem rozprawy i prace dotyczące dziejów władzy i historii prawa w porządku chronologicznym od starożytności aż po czasy współczesne. Obejmuje zatem prezentację zagadnień badawczych, które dotykają obszaru naukowych zainteresowań Jubilata, by wspomnieć przywołane powyżej prace na temat stosunków Korony i Litwy w XVIIII wieku czy europejskiego federalizmu.

Natomiast w drugim tomie, podzielonym na dwie części, zamieszczone zostały najpierw prace na temat historii szeroko rozumianej władzy wykonawczej, rządowej, administracji i sądownictwa administracyjnego. Z kolei w drugiej części znalazły się artykuły o historii nauki i idei, dobrze korespondujące z historią myśli administracyjnej i dziejom nauki i nauczania prawa, którym to kwestiom Jubilat poświęcił wiele swoich prac. Funkcji recenzenta jubileuszowego wydawnictwa podjął się prof. dr hab. Stanisław Waltoś.

Końcowym akcentem uroczystości było wystąpienie Profesora Jerzego Malca, w którym zaprezentował on krótką retrospekcję swej działalności naukowej tak w Uniwersytecie Jagiellońskim, jak i Krakowskiej Akademii. Jubilat złożył również serdeczne podziękowania wszystkim tym, którzy przyczynili się do zorganizowania uroczystości i wydania księgi jubileuszowej: jej redaktorom, autorom rozpraw i artykułów, którzy swym intelektem i nazwiskiem uświetnili jubileuszowe wydawnictwo, władzom i założycielom Krakowskiej Akademii oraz Krakowskiemu Towarzystwu Edukacyjnemu i Oficynie Wydawniczej Krakowskiej Akademii.

Uroczystość jubileuszu 40-lecia pracy naukowej Profesora Jerzego Malca przebiegła w niezwykle przyjaznej i miłej atmosferze, Jubilat cieszy się bowiem w środowisku historyków prawa niekłamanym uznaniem i szacunkiem. Familiarny nastrój uroczystości zapewnili także mówcy, nie stroniący od anegdot i dykteryjek w przekonaniu, że przemawiają do życzliwego Jubilatowi grona słuchaczy. Uroczystość uświetnił występ duetu akordeonowego studentów Krakowskiej Akademii Muzycznej.

ANDRZEJ DZIADZIO (Kraków)

\section{ZJAZD HISTORYKÓW DOKTRYN POLITYCZNYCH I PRAWNYCH W SZKLARSKIEJ PORĘBIE}

Doroczny Zjazd Katedr Doktryn Politycznych i Prawnych oraz Katedr Historii Doktryn Politycznych i Prawnych, który odbył się w dniach 23-25 października 2012 r. w Szklarskiej Porębie, został zorganizowany przez Katedrę Doktryn Politycznych i Prawnych Wydziału Prawa, Administracji i Ekonomii Uniwersytetu Wrocławskiego oraz Katedrę Doktryn Polityczno-Prawnych i Prawa Rzymskiego Wydziału Prawa i Administracji Uniwersytetu Opolskiego przy współudziale Polskiego Towarzystwa Myśli Politycznej. Konferencja spotkała się z dużym zainteresowaniem środowiska historyków doktryn, w tym gości zaproszonych z Australii, Japonii, Litwy i Ukrainy. 